\section{AZ INSURANCE EUROPE FELMÉRÉSE TÍZ EURÓPAI ORSZÁG LAKOSSÁGÁNAK NYUGDÍJCÉLÚ MEGTAKARÍTÁSAIRÓL}

Lambert Gábor, kommunikációs vezető MABISZ (gabor.lambert@mabisz.hu)

\section{ÖSSZEFOGLALÓ}

AzInsurance Europe tíz európai országra (köztük Magyarországra) kiterjedő felmérése szerint a felnőtt lakosságok közel felének egyáltalán nincs önálló nyugdij-megtakarítása, ugyanakkor túlnyomó többségük érdeklődést mutat a nyugdíjkiegészítés-célú megtakarítások iránt. Magyarországon az európai átlagnál kissé rosszabb a helyzet.

\section{SUMMARY}

According to a pension survey conducted by Insurance Europe covering $10 \mathrm{EU}$ members countries (including Hungary), almost half of the adult population are not saving for retirement, nevertheless majority of them are interested in doing so. The Hungarian situation is a little bit worse than the European average.

Kulcsszavak: egyéni nyugdíj-megtakarítások, nyugdífelmérés

Key words: private pension savings, pension survey

JEL: E21, G51

DOI: $10.18530 /$ BK.2020.3-4.102

http://dx.doi.org/10.18530/BK.2020.3-4.102
Az európai biztosítók nemzetközi szervezete, az Insurance Europe (IE) tavaly kezdeményezte a tagjai körében, hogy készüljön egy nemzetközi felmérés a lakosság öngondoskodási szokásairól, illetőleg a nyugdijtermékekkel kapcsolatos elvárásairól. AzIE ennek szükségességét azzal indokolta hogy az Európai Unió 80 év feletti népessége az elörejelzések szerint 2017 és 2080 között több mint kétszeresére növekszik, ami a nyugdíjrendszereket egész Európában jelentős nyomás alá helyezi. Becslések szerint évente mintegy 2 ezer milliárd euró kiegészítő nyugdij-megtakarításra lenne szükség Európában. Tapasztalható is, hogy szinte minden ország igyekszik arra ösztönözni az egyéneket, hogy kiegészítő nyugdij-megtakarítások révén vállaljanak felelősséget jövőbeli nyugdijjövedelmükért. A biztosítók kiemelt szerepet játszanak a nyugdíjhiány megszüntetésében, miután az egyéni kiegészítő nyugdíjtermékek legfőbb szolgáltatói közé tartoznak.

A kezdeményezésre tíz tagállam reagált pozitívan: Ausztria, Franciaország, Lengyelország, Luxemburg, Magyarország, Németország, Olaszország, Spanyolország, Svájc, valamint Portugália. Ennek nyomán a felmérést 2019 augusztusában és szeptemberében végezte el a gfs-zürich svájci piac- és társadalomkutató cég a tíz ország 10142 állampolgára körében. A válaszadók 49 százaléka volt nő, és 51 százalék férfi, életkoruk megoszlása: 35 százalék 18-35, 34 százalék 36-50, 31 százalék 51-65 év közötti. Az egyes országokban reprezentatívan jelenítették meg a különböző foglalkoztatottsági formákat (teljes, részmunkaidős, közalkalmazott, egyéni vállalkozó, munkanélküli vagy tanuló), az iskolai végzettségi szinteket (összességében 34 százalék felsőfokú, 55 százalék középfokú, 10 százalékáltalános iskolai végzettségü), illetve a családi státuszt. A kutatók az országonkénti, illetve az összesített felmérés táblázataiban külön is jelezték, ha valamelyik alcsoport véleménye szignifikánsan eltért az átlagtól.

\section{A kérdések csak a magán/kiegészítő nyugdíj-megtakarításokra} vonatkoztak.

Az online kérdőívek személyes vonatkozású kérdései kiszűrték azokat, akiknek a profilja nem felelt meg a célcsoportnak (pl. 18 év alattiak vagy már nyugdíjasok). A tizenegy tartalmi kérdésre (amelynek az angol nyelvű fogalmait a részt vevő országok biztosítási szövetségei ültettékát saját nyelvükre a helyi viszonyoknak megfelelően) megadott válaszok közül lehetett választani, adott esetben a kérdésre több válasz is megjelölhető volt. A lehetséges válaszokban megjelölt fogalmakat a kérdezők a legtöbb esetben világosan értelmezték is. A kérdések a válaszadók nyugdíj-megtakarítási megfontolásait, illetve pillanatnyi helyzetét kívánták felmérni, valamint azt, hogy miként készülnek pénzügyi szempontból a nyugdíjazásra, és mit várnak el a nyugdíj-megtakarításoktól. A felmérés elején tisztázták, hogy a kérdések csak a magán/kiegészítő nyugdíj-megtakarításokra vonatkoztak, tehát olyan egyéni tőkefelhalmozáson alapuló nyugdíj-megtakarításokra, amelyek

1) munkaszerződéshez vagy szakmai tevékenységhez kapcsolódnak (pl. foglalkoztató nyugdíppénztár, munkáltató által támogatott önkéntes nyugdíjpénztári befizetés, magánnyugdíjpénztár), vagy

2) melyekhez a csatlakozás önkéntes alapon, egyénileg történik (pl. nyugdíj-előtakarékossági számla (NYESZ), önkéntes nyugdíjpénztár, nyugdíjbiztosítás). 
Nem vonatkoztak tehát állami nyugdíjakra (kötelező társadalombiztosítási rendszer) és egyéb olyan nyugdij-megtakarítási formákra, mint ingatlan, valuta és bankbetétek.

A feldolgozott kérdőivek alapján elkészült tanulmányt az IE 2020. február 27-én mutatta be Brüsszelben. A tanulmány készítői szerint a válaszokból adódó öt legfontosabb megállapítás a következő:

- A válaszadók közel fele nem takarít meg a nyugdíjas éveire.

- A biztonság messze a legfontosabb prioritás, ha valaki nyugdij-megtakarításban gondolkodik.

- A megtakarítók már inkább digitálisan és nem papír alapon szeretnének információkhoz jutni.

- A részleteket illetően az egyes országok között lényegi különbségek vannak.

- A válaszokat a személyes körülmények - mint az életkor, a nem, a családi státusz, a képzettség szintje és a foglalkoztatási forma - is lényegesen befolyásolják.

Ezek mellett a válaszokból az is jól kiolvasható, hogy minél magasabb az informáltsági szint, annál jobban változnak a prioritások.

A részleteket illetően a legfontosabb megállapítás, hogy a válaszadók 43 százaléka nem rendelkezik még nyugdíjcélú megtakarítással, bár 62 százalékuk érdeklődését fejezte ki ezek iránt. A nem megtakarítók 42 százaléka ugyanakkor azt mondta, hogy jelenleg nem engedheti meg magának ilyen célú megtakarítás megkezdését. A jelenleg nem megtakarítók aránya az átlagnál magasabb a nők (47 százalék, míg a férfiaknál 40 százalék), a fiatalok (18-35 év között 47 százalék), az alacsonyabb iskolai végzettségűek (50 százalék) és a munkanélküliek, illetve részmunkaidőben dolgozók körében. Az eredményeket az 1., a 2. és a 3. ábra mutatja be.

1. ábra: Van-e megtakarítása nyugdij-kiegészítés céljából?

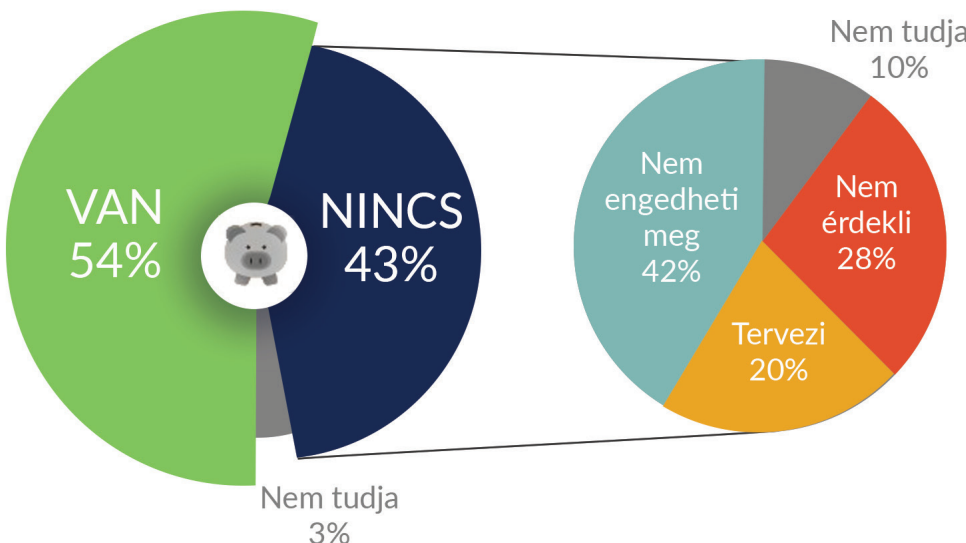

$3 \%$

Forrás: Insurance Europe, gfs-zürich
2. ábra: Nyugdíjcélú megtakarítással nem rendelkezők aránya

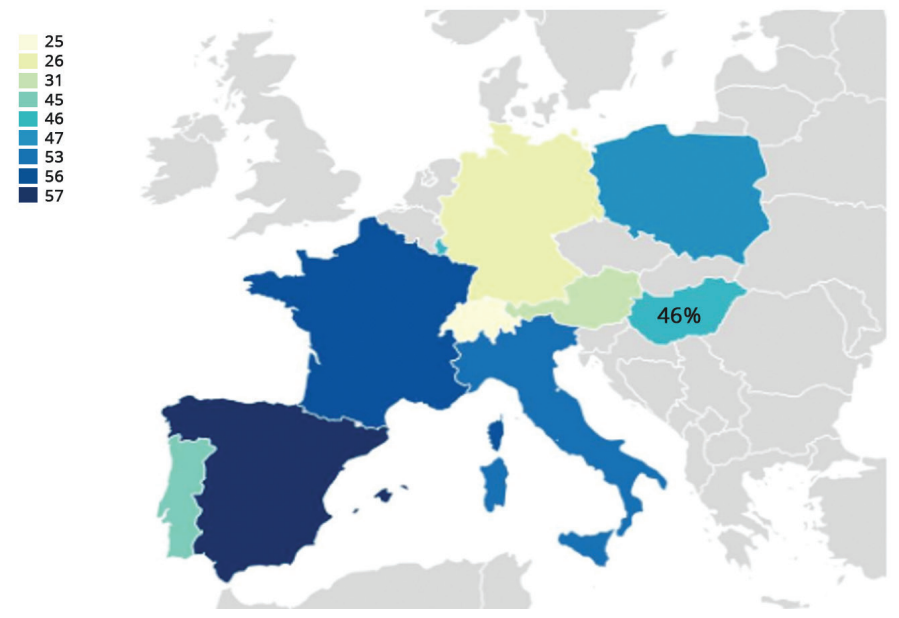

Forrás: Insurance Europe, gfs-zürich

3. ábra: Akit érdekel a nyugdíjcélú megtakarítás, de nem engedheti meg magának

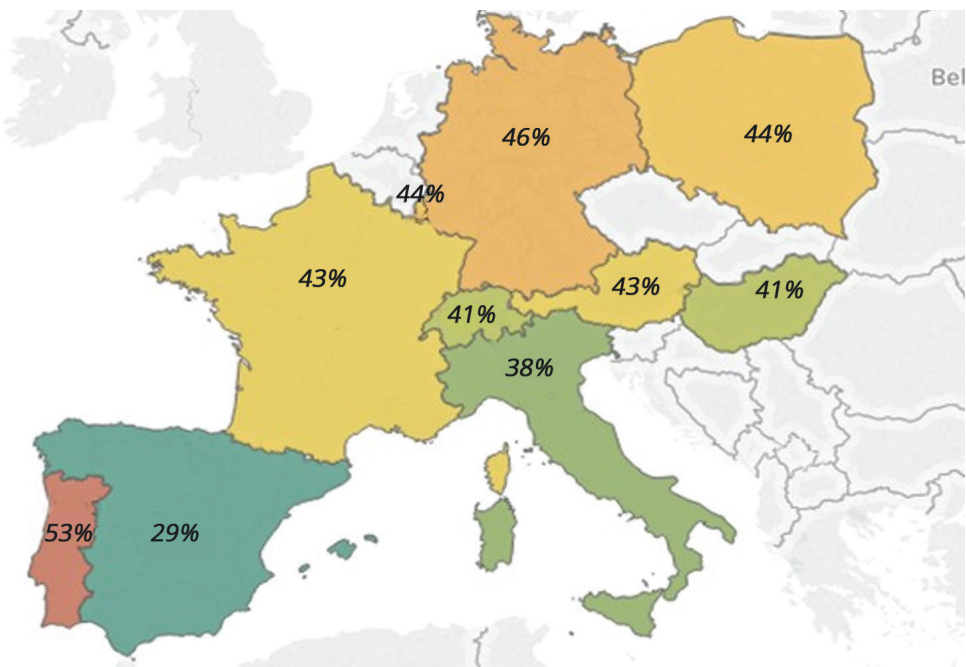

Forrás: Insurance Europe, gfs-zürich

Számos kérdés vonatkozott a nyugdíj-megtakarításokkal szembeni elvárásokra is. Messze a legfőbb prioritásnak számít a biztonság a befektetett összeget illetően, ezt a prioritási szempontok felsorolásakor 60 százalék tette az első helyre. Emellett a fizetési rugalmasság (hozzájárulás növelésének/felfüggesztésének lehetősége: 33\%), a megtakarítások örökölhetősége (32\%) és a likviditás (nyugdíj előtti hozzáférhetőség: $32 \%$ ) is fontos szempontok. 
A hosszú távú megtakarítások esetében kevésbé fontosnak tartották a válaszadók a költségeket (28\%), az adókedvezményeket (26\%), vagy éppen azt, hogyan teljesít a befektetésünk (14\%). A legkevésbé a megtakarítások hordozhatósága érdekelte őket Európán belül (10\%). Természetesen az életkor, a foglalkoztatási helyzet vagy a nem erősen befolyásolják az egyéni preferenciákat.

A biztonság vs hozam kérdése, vagyis hogy mibe fektessünk, különösen érdekes a biztosítók számára. Külön kérdés vonatkozott arra, hogy havi 32000 forint befektetése esetén milyen elvárásai vannak a megkérdezettnek húszéves távlatban:

- „Szeretnék bizonyos lenni abban, hogy legalább a befektetett összeget visszakapom, esetleg valamivel többet, így 32.000-45.000 forint közötti összeget kapok. (Ami 0\% és 1,75\% éves hozamnak felel meg 20 év után.)"

- „Szeretnék magasabb hozamban részesülni, még akkor is, ha ez azt jelenti, hogy el is veszithetem a pénzem egy részét, így 20.000-59.000 forint közötti összeget kapok. (Ami $-2,5 \%$ és 3\% éves hozamnak felel meg 20 év után.)"

A megkérdezettek 73 százaléka a kockáztatás helyett a biztonságot választotta, vagyis inkább szeretne bizonyos lenni abban, hogy legalább a befektetett összeget visszakapja majd. A nők 78, a részidős munkások 77 és a férfiak 68 százaléka százaléka nyilatkozott így. (4. ábra)

\section{4. ábra: Erös igény a garanciák iránt}

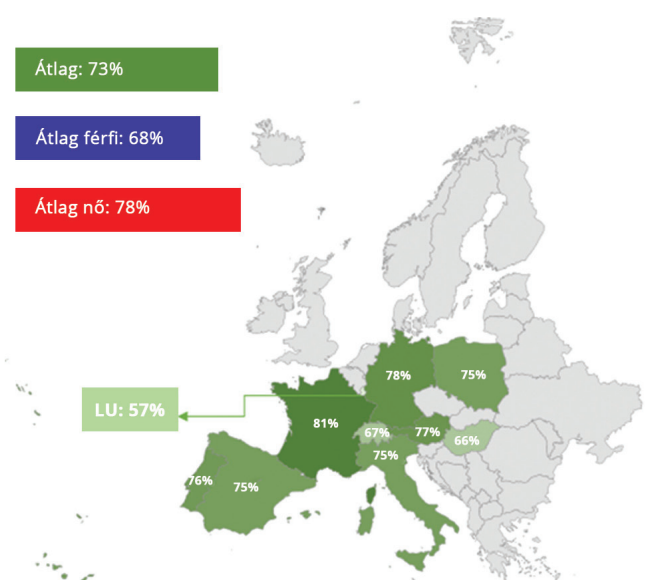

Forrás: Insurance Europe, gfs-zürich

A biztosítók által kínált nyugdijtermékek egy része széles körü kockázatokkal - például halálozás, rossz egészségi állapot - szemben, illetve hosszú élettartam esetén is képesek pénzügyi védelmet nyújtani. A megkérdezettek szignifikáns hányada hajlandó fizetni is ilyen kiegészítő fedezetekért. (Zárójelben a százalékos arány, hogy hányan fizetnének az adott, nyugdíj-megtakarítást kiegészítő fedezetért.)
- Védelem arra az esetre, ha a vártnál tovább élek, és felélem a megtakaritásaimat." (Ún. longevity risk: 43\%)

- „Védelem a kedvezményezettjeimnek arra az esetre, ha a nyugdijkorhatár elérése elött/után halok meg". (Ún. mortality risk: 46\%).

- „Védelem, amely lehetővé teszi számomra, hogy továbbra is fizessem a nyugdij-megtakaritási összeget, ha sérülés/rokkantság miatt elveszitem a jövedelmemet". (Ün. morbidity risk: 40\%)

Kicsit mellékvágány, de érdekes és a longevity risk szempontjából lehet lényeges, hogy a felmérés rákérdezett a válaszadóknál, mit gondolnak, hány évig fognak élni. Az adott ország statisztikai átlagához közeli válaszok születtek, amit az 5. ábrán láthatunk.

\section{5. ábra: Egyének becsült várható élettartama}

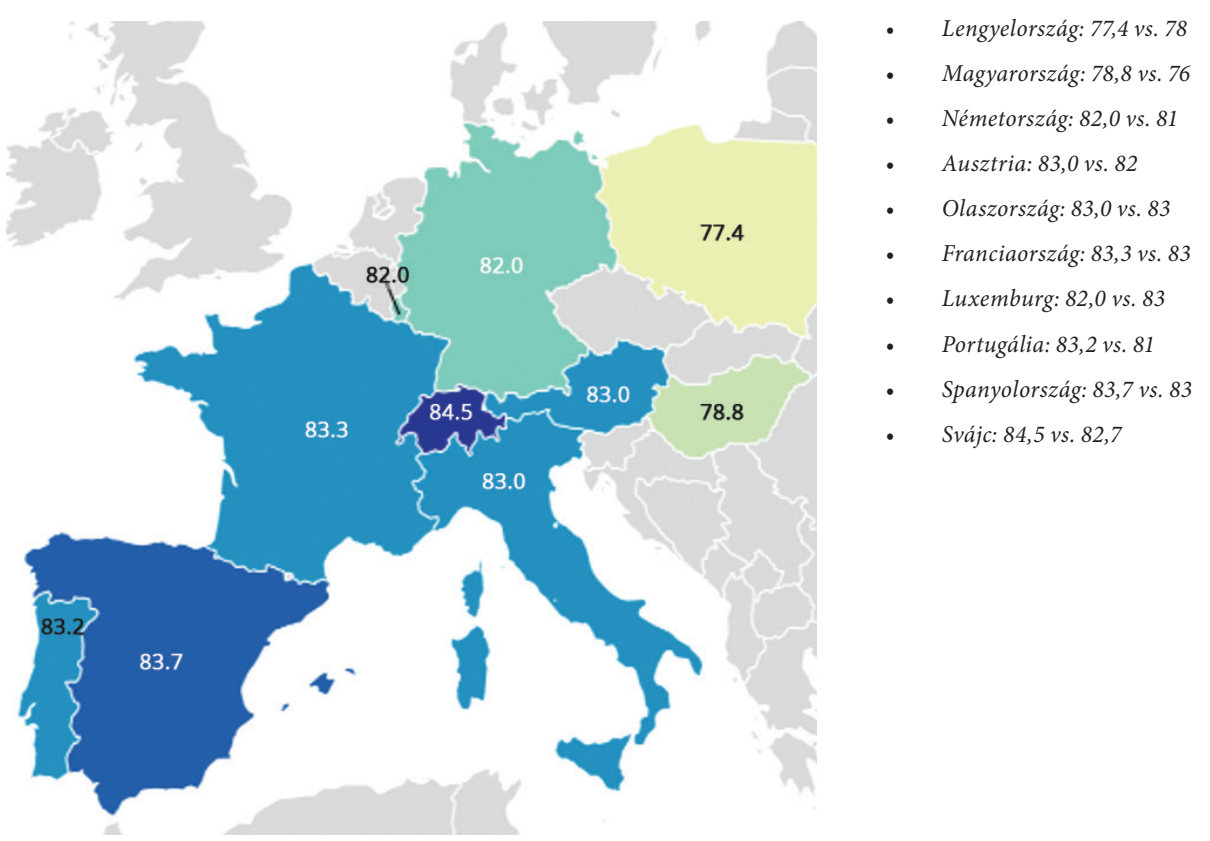

Forrás: Insurance Europe, gfs-zürich

Ami a kifizetési preferenciákat illeti, a válaszadók többsége elvben általában a járadékfizetést („egy elöre meghatározott, rendszeres jövedelmet kapni az életem hátralévő részében”: 46\%) és a rugalmas kivéteket rendszeres időközönként (30\%) preferálja az egyösszegủ kifizetés („a nyugdíj során magam kezelem a tőkémet": 19\%) helyett. (A nyugdíj-megtakarítás más célokra történő felhasználását, például adósságfizetésre, ingatlanvásárlásra, egyéb kiadásokra csak 5 százalék preferálta). Viszont itt azt tapasztaljuk, hogy több, pontosabb információ hatására módosulnak 
a preferenciák. A következő lépésben az általánosság helyett úgy konkretizálták a kérdést, hogy amikor a válaszadó nyugdijba megy, melyik lehetőséget részesítené előnyben?

A. 16000 000 forintot kapni egy összegben nyugdijba vonuláskor”

B. „810000 forintot kapni nyugdijba vonulás után minden évben életem hátralévő részében”

Ezekre a lehetőségekre már fele-fele arányban oszlottak meg a válaszok.

Arról, hogy a nyugdíjjal kapcsolatos megalapozott döntések meghozatalához a megtakarítóknak megfelelő információkra van szükségük, egy másik kérdéscsoportból is megerősítést kapunk. („Mielőtt megvásárolna egy nyugdijterméket, milyen információt tartana különösen fontosnak a választásnál?” Illetve: „Miután megvásárolt egy nyugdijterméket, milyen információt tartana különösen fontosnak a nyugdijhelyzetének felmérésénél?" Mindkét esetben legfeljebb öt válasz megjelölésére kérték a kitöltőket.) A válaszadókat leginkább a garanciákkal kapcsolatos információk érdeklik mind szerződéskötés előtt (64\%), mind a szerződést követően (51\%). A tájékozódás szintjén már a második legfontosabb dologként jöttek elő a költségek (,, a lehetö legkevesebb költséget szeretném még akkor is, ha a szolgáltatás mértéke és minősége alacsonyabb": 63, illetve 50\%), harmadik helyen a kockázatok (például lehetséges veszteségek: 56 vs. 42\%), majd a kifizetési formákkal (46 vs. 41\%) és a befektetési teljesítménnyel (43 vs. 43\%) kapcsolatos információk. A legkevésbé fontosnak a befektetési stratégiákkal, az országok közötti hordozhatósággal és a szolgáltatóváltással kapcsolatos információk számítanak.

A nyugdíjjal kapcsolatos megalapozott döntések meghozatalához a megtakarítóknak megfelelő információkra van szüikségüik.

A megkérdezettek 67 százaléka ezeket az információkat digitálisan szeretné megkapni. Különösen a felsőfokú végzettségűek (74\%), a férfiak (71\%), illetve a 18-35 év közöttiek (70\%) körében magas ez az igény, bár a fiatalok tekintetében akár meglepetésként is értelmezhető az átlag közeli érték.

A további részletek, az egyes országok eltérései a benchmarktól, illetve azon belül a kirívóan eltérő válaszokat adó alcsoportok különbözősége természetesen még számos érdekességet kínál az elmélyült kutatóknak, árnyaltabb következtetésekkel. Számunkra most a magyar sajátosságok, illetve az átlagtól való eltérések lehetnek érdekesek.

A magyar válaszadóknak az átlagnál magasabb része, 46 százalékuk válaszolt úgy, hogy nem rendelkezik még nyugdíjcélú megtakarítással, bár 59 százalékuk érdeklődését fejezte ki ezek iránt. (6. ábra) A magyar fiatalok körében 53 százalék azoknak az aránya, akik nem rendelkeznek nyugdíjcélú megtakarítással, és az alsófokú végzettségűek körében is magas (62\%) az arány. Az európai átlagnál alacsonyabb magyarországi nyugdíj-megtakarítási hajlandóságot már korábbi felmérés is megállapította. (Horváth, 2016)
6. ábra: A jelenleg NEM megtakarító magyarok többsége érdeklődést mutat

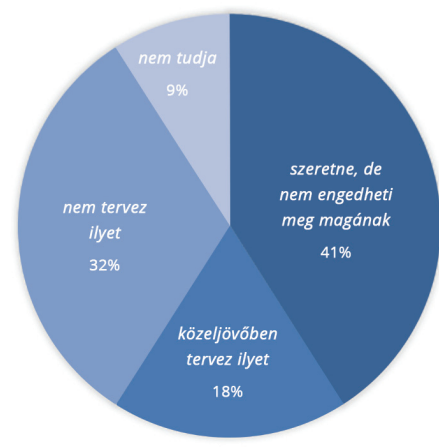

Forrás: Insurance Europe, gfs-zürich

A megtakarításokkal rendelkezők körében a különböző nyugdijtermékek megoszlása hasonló a benchmarkhoz, az egyéni és munkáltatói nyugdítermékek dominálnak. (Munkáltatóinak minősül például a foglalkoztatói nyugdíjpénztár, munkáltató által támogatott önkéntes nyugdíjpénztári befizetés, magánnyugdíjpénztár. Egyéni például a nyugdíjbiztosítás, NYESZ, egyénileg fizetett önkéntes nyugdípénztár. Az egyebekben például az életbiztosítások értendők, de nem tartoznak ide a bankbetétek, megtakarítási számlák és az ingatlan.) (7. ábra)

7. ábra: Nyugdíjcélú megtakarítások jelenlegi helyzete
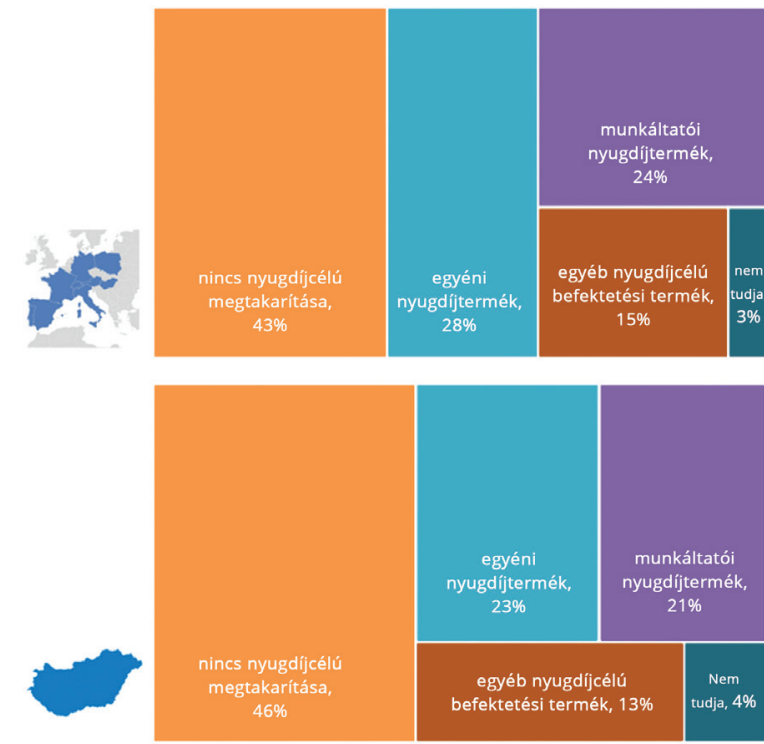

Forrás: Insurance Europe, gfs-zürich 
A magyar megtakarítók szintén a garanciát tekintik a legfontosabbnak, azt, hogy legalább a befektetett összegeiket visszakapják, de a benchmarknál lényegesen többen tartják fontosnak az örökölhetőséget és a fizetési rugalmasságot (szüneteltetés, többletbefizetés lehetösége), és kevesebbre értékelik a likviditást (a megtakarításhoz való hozzáférést a nyugdíj előtt). (8. ábra)

8. ábra: Nyugdíj-megtakarítással kapcsolatos preferenciák

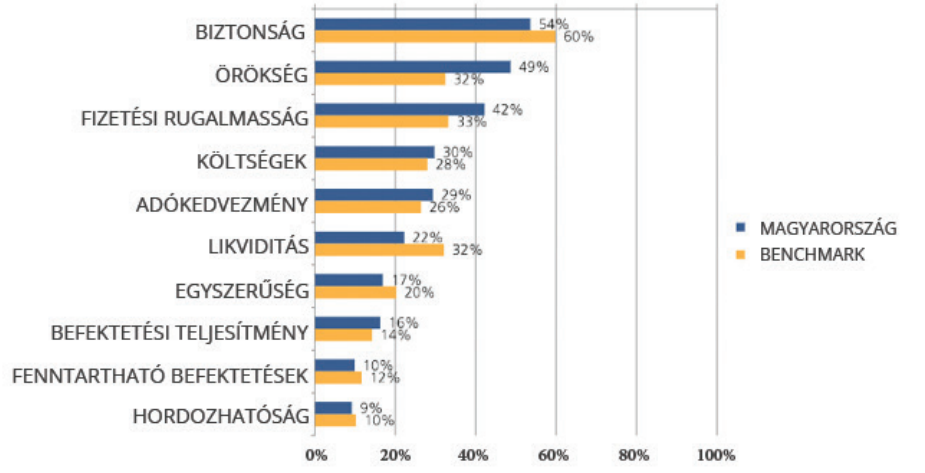

Forrás: Insurance Europe, gfs-zürich

A többi európai országhoz képest kevésbé biztonsági játékos a magyar. Hosszú távú - húszéves - befektetéseik kapcsán a benchmarknál lényegesen kevesebben (57\%) szeretnének biztosak lenni abban, hogy legalább a befektetett összeget visszakapják, 43 százalék hajlandó kockáztatni az esetleges magasabb hozam érdekében. Némileg meglepő módon a 35 év alatti fiatalok (64 vs. 36\%), valamint a nők (60 vs. 40\%) óvatosabbak az európai átlagnál, míg a férfiak (54 vs. $46 \%$ ) vakmerőbbek.

A biometrikus kockázatok közül leginkább a halálozási kockázat nyugtalanítja a magyarokat. A viszonyítási átlagnál szignifikánsan többen, 55 százaléknyian lennének hajlandóak fizetni a nyugdíj-megtakarításuk kiegészítő fedezeteként azért, hogy a kedvezményezettek a biztosított elhalálozása esetén védelmet élvezzenek. Túlélési kockázatra 40 százalék, betegségi kockázatra 42 százalék lenne hajlandó kiegészítő biztosítást kötni.

A kifizetéssel kapcsolatban a magyar elképzelések nem térnek el lényegesen az európai átlag tól. Valamivel kevesebben szeretnének járadékot, valamennyivel többen rugalmas kivétek lehetőségét rendszeres időközönként, és a fele-fele európai aránnyal szemben 49 százaléknyian szeretnék egy összegben felvenni a nyugdíjkorhatárt elérve a 16 millió forintot, 51 százalék inkább az évi 810 ezer forintos járadékot választaná. (9. ábra)
9. ábra: Kifizetéssel kapcsolatos preferenciák

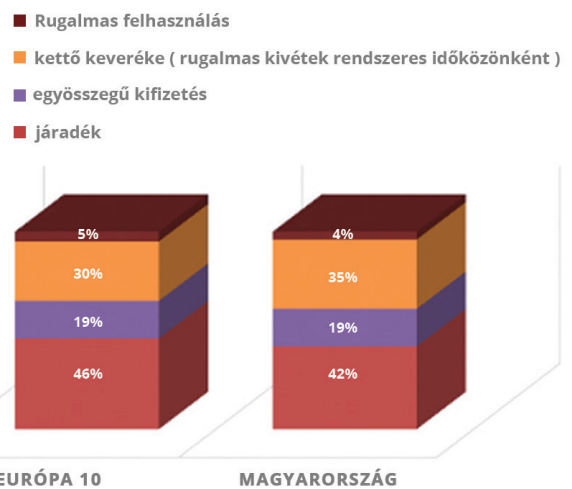

Forrás: Insurance Europe, gfs-zürich

A szerződéskötés előtt, illetve azt követően elvárt információk a magyar válaszadók esetében hasonlóak a benchmarkhoz, ugyanaz az öt legfontosabb, csak más sorrendben. A legfontosabbak a garanciák (legalább a befektetett tőkét szeretném visszakapni), de ezt követően a hozamról, a költségekről, a kockázatokról, illetve a kifizetési formákról szeretnénk leginkább tájékozódni, mind szerződéskötés előtt, mind pedig utána. A benchmarknál szignifikánsan nagyobb szerepe van az adókedvezményekről kapott információknak is. (10. ábra)

10. ábra: Fontosnak tartott információk

$0 \% \quad 20 \% \quad 40 \% \quad 60 \% \quad 80 \%$

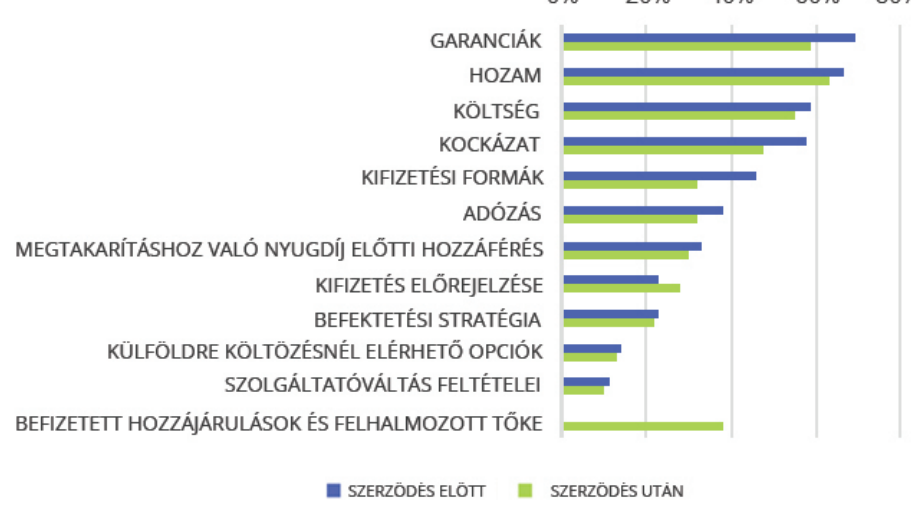

Forrás: Insurance Europe, gfs-zürich

A digitális formában való tájékoztatás igénye valamivel magasabb, mint a benchmark (70\%), de itt is meglepő, hogy a korosztályok tekintetében a 35 év alattiak körében a legalacsonyabb (68\%). (11. ábra) 
11. ábra: Digitális tájékoztatás iránti igény

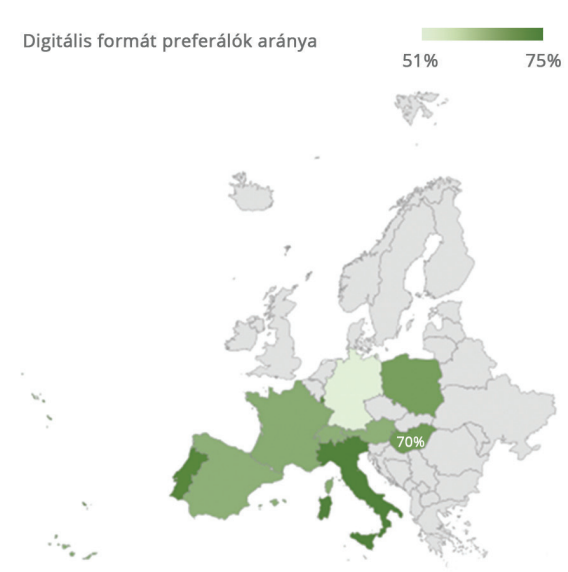

Forrás: Insurance Europe, gfs-zürich

A felmérés alapján az Insurance Europe szakértői úgy látják, hogy az európai lakosság körében tovább kell növelni a pénzügyi tudatosságot, illetve a nyugdíjcélú megtakarítások iránti igény szükségességét. A nyugdijtermékeknek pedig fogyasztóközpontúaknak kell lenniük, és valós igényeken, valamint szükségleteken kell alapulniuk.

\section{IRODALOMJEGYZÉK}

Insurance Europe: Pension Surver

https://insuranceeurope.eu/what-do-europeans-want-their-pension-savings Letöltés ideje: 2020.09.11

Horváth Gyula: Felkészültünk a nyugdijira? Biztositás és Kockázat 3. évfolyam 3. szám

https://mabisz.hu/wp-content/uploads/2018/08/biztositas-es-kockazat-3-evf-3-szam-5-cikk.pdf
http://dx.doi.org/1018530/BK.2016.3.80 Letöltés ideje: 2020.09.11 